OPEN ACCESS

Edited by:

Marie-Joelle Virolle,

Centre National de la Recherche Scientifique (CNRS), France

Reviewed by:

Nengguo Tao,

Xiangtan University, China Alessandra Zambonelli,

University of Bologna, Italy

${ }^{*}$ Correspondence: Zhongyang Ding bioding@163.com

Specialty section:

This article was submitted to Microbial Physiology and Metabolism,

a section of the journal

Frontiers in Microbiology

Received: 03 June 2019 Accepted: 20 September 2019 Published: 15 October 2019

Citation:

Ma Z, Xu M, Wang Q, Wang F Zheng H, Gu Z, Li Y, Shi G and Ding Z (2019) Development of an Efficient

Strategy to Improve Extracellular

Polysaccharide Production

of Ganoderma lucidum Using

L-Phenylalanine as an Enhancer.

Front. Microbiol. 10:2306.

doi: 10.3389/fmicb.2019.02306

\section{Development of an Efficient Strategy to Improve Extracellular Polysaccharide Production of Ganoderma lucidum Using L-Phenylalanine as an Enhancer}

\author{
Zhongbao Ma1,2, Mengmeng Xu',2, Qiong Wang ${ }^{1,2}$, Feng Wang ${ }^{3}$, Huihua Zheng ${ }^{4}$, \\ Zhenghua Gu ${ }^{1,2}$, Youran Li $^{1,2}$, Guiyang Shi ${ }^{1,2}$ and Zhongyang Ding ${ }^{1,2 *}$ \\ ${ }^{1}$ Key Laboratory of Carbohydrate Chemistry and Biotechnology, Ministry of Education, School of Biotechnology, Jiangnan \\ University, Wuxi, China, ${ }^{2}$ National Engineering Laboratory for Cereal Fermentation Technology, Jiangnan University, Wuxi, \\ China, ${ }^{3}$ School of Food and Biological Engineering, Jiangsu University, Zhenjiang, China, ${ }^{4}$ Jiangsu Alphay Biological \\ Technology Co., Ltd., Nantong, China
}

Ganoderma lucidum has been a well-known species of basidiomycetes for a long time, and has been widely applied in the fields of food and medicine. Based on the simulation results of model iZBM1060 in our previous research, the effect of L-phenylalanine on G. lucidum extracellular polysaccharides (EPSs) was investigated in this study. EPS production reached $0.91 \mathrm{~g} / \mathrm{L}$ at $0.4 \mathrm{~g} / \mathrm{L} \mathrm{L}$-phenylalanine after a $24 \mathrm{~h}$ culture, which was $62.5 \%$ higher than that of control $(0.56 \mathrm{~g} / \mathrm{L})$. Transcriptome and genome analysis showed that L-phenylalanine deaminase and benzoate 4-hydroxylase (related to L-phenylalanine metabolism) were significantly up-regulated, while the cell wall mannoprotein gene was down-regulated. Transmission electronic microscopy (TEM) and atomic force microscopy results showed that the cell wall thickness decreased by $58.58 \%$, and cell wall porosity increased in cells treated with L-phenylalanine, which probably contribute to the increasing EPS production. This study provides an efficient strategy for fungal polysaccharide production with high output and low cost.

Keywords: Ganoderma lucidum, extracellular polysaccharide, L-phenylalanine, cell wall, efficient strategy

\section{INTRODUCTION}

Ganoderma lucidum is an important variety of mushroom that possesses a wide range of biological activities. G. lucidum polysaccharide, as one of the main bioactive substances with a complex structure, has been studied for its anticancer and immunomodulatory activities (Liu et al., 2010; Ferreira et al., 2015; Xiang et al., 2018; Zhen et al., 2018). In the latest studies, liquid fermentation technology of G. lucidum prospered due to its ability to enhance mycelial biomass and produce more bioactive compounds with high efficiency (Zhou et al., 2014; Wei et al., 2016, 2018).

Great efforts have been made to improve the polysaccharide production of G. lucidum. In our previous research, the G. lucidum genome metabolic model iZBM1060 was reconstructed.

Abbreviations: AFM, atomic force microscope; DW, dry weight; EPS, extracellular polysaccharide; IPS, intracellular polysaccharide; KAAS, KEGG automatic annotation server; TEM, transmission electronic microscopy. 
The simulation and predictions based on this model indicated that L-phenylalanine had a significant promoting effect on the production of EPSs (Ma et al., 2018). L-phenylalanine is an aromatic amino acid with physiological activities; it is one of the essential amino acids that cannot be naturally synthesized by the human body and animals and is widely applied in the food and medicine industries (Bongaerts et al., 2001). To our best knowledge, few studies have investigated the impacts of L-phenylalanine on the cultivation of edible and medicinal fungi.

In this study, an efficient strategy for EPS production with high output was established by adding L-phenylalanine to the culture of G. lucidum. The possible metabolic pathway of L-phenylalanine in G. lucidum was elucidated, and the mechanism of L-phenylalanine that promotes EPS production was also investigated.

\section{MATERIALS AND METHODS}

\section{G. Iucidum Strain and Culture Conditions}

Ganoderma lucidum CGMCC5.26 was purchased from the China General Microbiological Culture Collection Center (Beijing). It was preserved on potato dextrose agar (PDA) slants at $4^{\circ} \mathrm{C}$. The composition of the seed and submerged fermentation medium ( $\mathrm{g} / \mathrm{L})$ is as follows: glucose (20), tryptone (5), yeast nitrogen base without amino acids (YNB) (5), and $\mathrm{MgSO}_{4} \cdot 7 \mathrm{H}_{2} \mathrm{O}$ (2), $\mathrm{KH}_{2} \mathrm{PO}_{4}$ (4.5), with culture conditions of $30^{\circ} \mathrm{C}$ at $150 \mathrm{rpm}$ (Ma et al., 2018).

Medium A (g/L) (Tang and Zhong, 2002) contained glucose (35), tryptone (5), yeast extract (2.5), $\mathrm{KH}_{2} \mathrm{PO}_{4} \cdot \mathrm{H}_{2} \mathrm{O}$ (1), $\mathrm{MgSO}_{4} \cdot 7 \mathrm{H}_{2} \mathrm{O}(0.5)$, and Vitamin $\mathrm{B}_{1}$ (0.05), with culture conditions of $30^{\circ} \mathrm{C}$ at $150 \mathrm{rpm}$. Medium B (g/L) (Hu et al., 2018) contained glucose (20), tryptone (2), yeast extract 2, $\mathrm{KH}_{2} \mathrm{PO}_{4}$ (4.6), and $\mathrm{MgSO}_{4} \cdot 7 \mathrm{H}_{2} \mathrm{O}(0.5)$, with culture conditions of $30^{\circ} \mathrm{C}$ at $150 \mathrm{rpm}$.

The seed culture included four mycelium agar squares $(3 \mathrm{~mm} \times 3 \mathrm{~mm})$, which were transferred into a $250 \mathrm{~mL}$ flask and cultured for 7 days. The fermentation culture was developed as follows. After homogenization with a high-speed tissue homogenate machine (IKA T10 basic ULTRA-TURRAX), a $3 \mathrm{~mL}$ of the seed culture solution was inoculated into a $500 \mathrm{~mL}$ flask and cultured for 7 days (Peng et al., 2015).

\section{Determination of the Biomass, Residual Sugar in Medium, EPS, and IPS}

After the end of fermentation, mycelium was obtained by centrifugation $(10,000 \mathrm{rpm}, 10 \mathrm{~min})$; it was then washed with distilled water three times and dried to a constant weight $\left(60^{\circ} \mathrm{C}\right)$. The DW was measured by the gravimetric method.

For EPS, we added 95\% (v/v) ethanol (four times) into the above supernatant, then stirred it evenly and placed it in a $4^{\circ} \mathrm{C}$ environment for $8 \mathrm{~h}$. Crude EPSs were acquired through centrifugation $(8,000 \mathrm{rpm}$ for $20 \mathrm{~min})$, washed with $80 \%(\mathrm{v} / \mathrm{v})$ ethanol three times, and further dried to remove the residual ethanol $\left(60^{\circ} \mathrm{C}\right)$. The phenol-sulfuric acid method was used to determine the total EPS content (Dubois et al., 1951).
For the IPS analysis (Stajic et al., 2011), $100 \mathrm{mg}$ mycelia powder was suspended in $10 \mathrm{~mL} \mathrm{H}_{2} \mathrm{O}$ at $100^{\circ} \mathrm{C}$ for $3 \mathrm{~h}$. The supernatant was then collected by centrifugation $(8,000 \mathrm{rpm}$ for $20 \mathrm{~min}$ ) and the supernatant volume was recorded. The extraction method of IPS in the supernatant was the same as that of EPS. The total IPS content was assayed by the phenolsulfuric acid method.

\section{Ultra-Structural Analysis of G. Iucidum}

In order to detect the function of L-phenylalanine on the ultrastructure, G. lucidum cells were analyzed by TEM. G. lucidum cells were fixed in $5 \%$ glutaraldehyde $(0.1 \mathrm{M}$ phosphate buffer, $\mathrm{pH}$ 7.2) and then rinsed with $0.1 \mathrm{M}$ phosphate buffer. Next, the cells were fixed again with $1 \%$ osmium acid $(0.1 \mathrm{M}$ phosphate buffer, $\mathrm{pH}$ 7.2) and rinsed with $0.1 \mathrm{M}$ phosphate buffer. The cell samples were dehydrated with ethanol and embedded in Epon 812 resin. Finally,the embedded cells were sliced and then stained in a saturated uranyl acetate and aqueous lead citrate solution and placed in a TEM (HITACHI H-7650) to observe theie ultra-structures (Armando et al., 2012).

The thickness of the cell wall was measured near the equatorial cut surfaces using the Image J software. To guarantee the accuracy of the analysis, we only selected the cells of approximately the same size, and the cells were cut longitudinally (Tavernier et al., 2018).

To observe the cell surface, the mycelium was washed three times with sterile water and then homogenized. The sample was placed on the silicon wafer $(0.5 \mathrm{~cm} \times 0.5 \mathrm{~cm})$. The silicon wafer was mounted on a steel disc using two-sided tape. The steel disc was then magnetically attached to the piezoscanner. The microstructures of the samples were observed by an AFM (Bruker MultiMode 8). The images were then analyzed and processed using NanoScope Analysis (Kim et al., 2007).

\section{RNA Sequencing and Gene Expression Analysis}

The total RNA from the mycelial samples with and without the addition of L-phenylalanine was extracted using an RNeasy Mini Kit (Qiagen, Hilden, Germany) according to the manufacturer's protocol. Then, RNA degradation and contamination, purity, concentration, and integrity were measured using 1\% agarose gels, a NanoPhotometer spectrophotometer (IMPLEN, Westlake Village, CA, United States), a Qubit RNA Assay Kit in Qubit 2.0 Fluorometer (Life Technologies, Carlsbad, CA, United States), and an RNA Nano 6000 Assay Kit of the Agilent Bioanalyzer 2100 system (Agilent Technologies, Santa Clara, CA, United States), respectively (Guan et al., 2018; Liu et al., 2018).

A total of $1.5 \mu \mathrm{g}$ RNA per sample was used to prepare the sequencing libraries using the NEBNext Ultra ${ }^{\text {TM }}$ RNA Library Prep Kit for Illumina (NEB, United States) following the manufacturer's recommendations. The final PCR products were sequenced via Illumina HiSeq ${ }^{\mathrm{TM}} 2500$ (Novogene Co., Ltd., Beijing, China). Before proceeding with the analysis, two steps (removing reads containing the adapter, reads containing ploy$\mathrm{N}$, and low quality reads and calculating Q20, Q30, GC-content, and sequence duplication level) were needed to confirm that the 
clean data quality was sufficient for the sequence assembly and subsequent analysis. Transcriptome assembly was accomplished based on the left.fq and right.fq using Trinity. A subsequent analysis was performed by genome mapping (based on the G. lucidum 5.26 genome sequence), functional gene annotation and classification (using the following databases: Nr, Nt, Pfam, KOG/COG, Swiss-Prot, KO and GO). Gene expression levels were calculated using TPM (Transcripts Per Kilobase of exon model per Million mapped reads) (Gu et al., 2017). Differentially expressed genes were identified according to the threshold of the $q$-value $<0.005$ (Storey, 2003) and $\mid \log _{2}$ (Fold change) $\mid>1$ by using the DEGseq (2010) R package (Robinson et al., 2010).

\section{Real-Time Quantitative PCR Analysis of Gene Expression}

The transcription levels of the GL21534-R1, GL28294-R1, and GL18553-R1 genes (which encode the enzymes of L-phenylalanine deaminase, benzoate 4-hydroxylase, and the cell wall mannoprotein, respectively) were analyzed by real-time quantitative PCR (RT-qPCR). The PCR reaction procedure was as follows. After denaturation at $95^{\circ} \mathrm{C}$ for $10 \mathrm{~min}$, the amplification was divided into denaturation at $95^{\circ} \mathrm{C}$ for $15 \mathrm{~s}$,

TABLE 1 | Oligonucleotide primers used in this study.

\begin{tabular}{lll}
\hline Target gene & Primer name & Sequence $\left(\mathbf{5}^{\prime} \boldsymbol{\rightarrow} \mathbf{3}^{\prime}\right)$ \\
\hline pal & pal-F & GCTCATCGGCAACCCATCTA \\
& pal-R & CCGTTGAGGATACCGAGGTG \\
bpha & bpha-F & GGGTGTGGTACGACTGTCTG \\
& bpha-R & GAGTCCTACACGCGAGGAG \\
pir & pir-F & TCGCCAAACCGTGCATTC \\
& pir-R & GGGTTGCGGAGACATGAGA \\
rns & rns-F & GAGAAACGAAGGTAGGGTAGG \\
& rns-R & CACAAGGCGGAATGGTATTG
\end{tabular}

annealing at $60^{\circ} \mathrm{C}$ for $1 \mathrm{~min}$, and extension at $60^{\circ} \mathrm{C}$ for $15 \mathrm{~s}(\mathrm{Xu}$ et al., 2010). The rns was used as a reference gene, as reported previously (Li et al., 2013). The expression of the related genes was calculated according to the $2^{-\Delta \Delta C_{t}}$ method (Livak and Schmittgen, 2001). The primers used are listed in Table $\mathbf{1}$.

\section{Quantification of $\beta-1,3-$ Glucan and Chitin}

Mycelium powder was suspended in distilled water, and cell fragmentation was obtained by ultrasonication for $10 \mathrm{~min}$ (300 W, 30\% duty cycle, Sonics 750). The degree of cell breakage was observed by microscope. The broken cells were washed by the washing solution in the following order: washing solution A [1 mM phenylmethylsulfonyl fluoride (PMSF)], washing solution $\mathrm{B}[5 \%(\mathrm{w} / \mathrm{v}) \mathrm{NaCl}, 1 \mathrm{mM}$ PMSF], washing solution C [2\% (w/v) $\mathrm{NaCl}, 1 \mathrm{mM}$ PMSF], washing solution D [1\% (w/v) $\mathrm{NaCl}, 1 \mathrm{mM}$ PMSF], and then the intracellular contaminants were removed with wash solution A (Chen et al., 2012). Each step was repeated three times, and the isolated cell wall material was lyophilized.

The $\beta$-1,3-glucan and chitin concentrations were measured using a previously described method (Fortwendel et al., 2009). The measurement of $\beta$-1,3-glucan was as follows. A $20 \mathrm{mg}$ cell wall sample was suspended in a $2 \mathrm{~mL} 1 \mathrm{M} \mathrm{NaOH}$ solution and mixed, It was then incubated $\left(52^{\circ} \mathrm{C}\right.$ for $\left.30 \mathrm{~min}\right)$. A total of $0.5 \mathrm{~mL}$ of supernatant was aliquoted into a new tube, and $1.85 \mathrm{~mL}$ of an aniline blue mix was added for incubation $\left(52^{\circ} \mathrm{C}\right.$ for $30 \mathrm{~min}$ ). The fluorescence value was detected via fluorescence spectrophotometer (HITACHI F-7000) at $405 \mathrm{~nm}$ excitation and $460 \mathrm{~nm}$ emission. The $\beta$-1,3-glucan content was expressed as the relative fluorescence unit percentage per milligram of mycelium.

The measurement of the chitin was performed as follows. A $20 \mathrm{mg}$ cell wall sample was added to $3 \mathrm{~mL}$ of a saturated $\mathrm{KOH}$ solution at $130^{\circ} \mathrm{C}$ for $1 \mathrm{~h}$. After cooling to room temperature, the sample was added to $10 \mathrm{~mL}$ of an ice-cold $75 \%(\mathrm{v} / \mathrm{v})$ ethanol solution, shaken to form a suspension, and then given an ice bath for $15 \mathrm{~min}$. Next, after adding $0.9 \mathrm{~mL}$ of $13.3 \%(\mathrm{w} / \mathrm{v})$
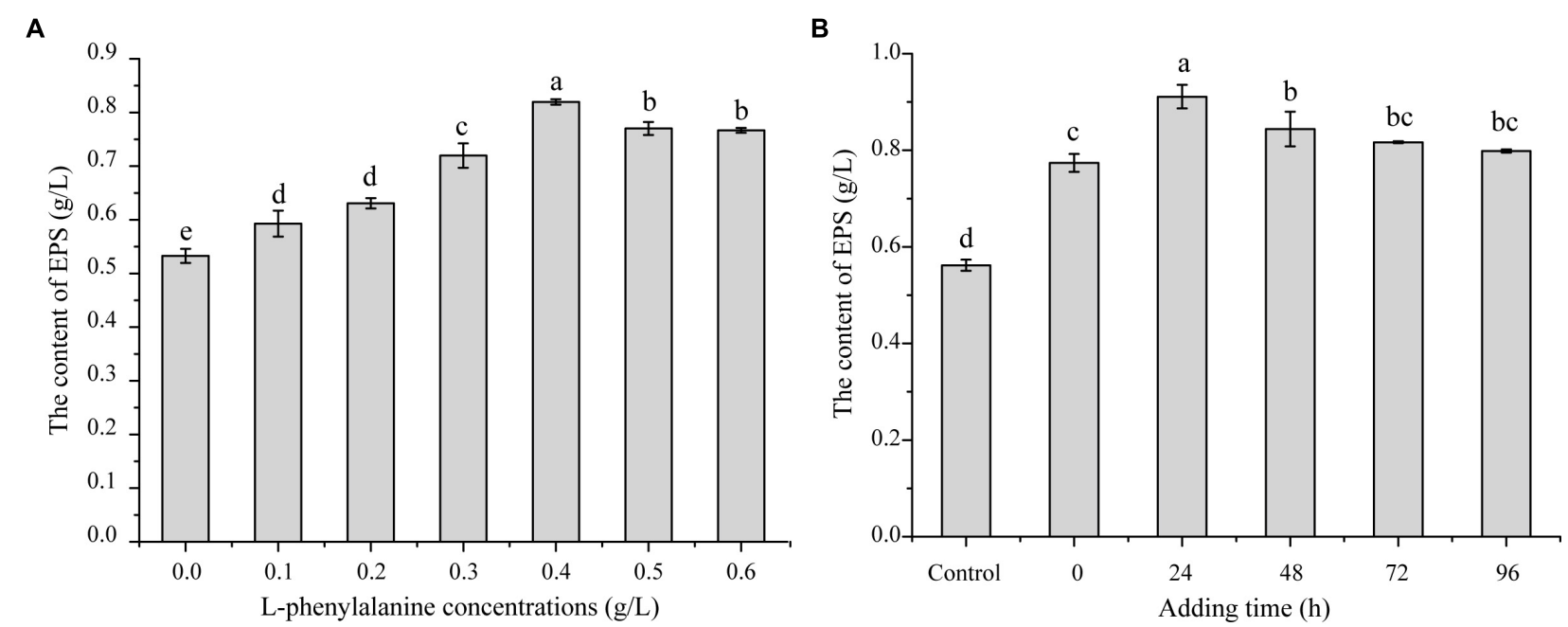

FIGURE 1 | The effect of L-phenylalanine on EPS production in G. lucidum. (A) Effects of L-phenylalanine concentrations on EPS. (B) Effects of L-phenylalanine $(0.4 \mathrm{~g} / \mathrm{L})$ addition at different stage on EPS [the different superscript letters $(\mathrm{a}, \mathrm{b}, \mathrm{c}, \mathrm{d})$ in each column indicate significant differences at the $P<0.05$ level]. 
celtite 545, the mixture was shaken for $5 \mathrm{~min}$ and centrifuged at $4^{\circ} \mathrm{C}$ at $5,000 \mathrm{rpm}$ for $5 \mathrm{~min}$. The precipitation was cleaned by $10 \mathrm{~mL}$ of ice-cold $40 \%(\mathrm{v} / \mathrm{v})$ ethanol and $10 \mathrm{~mL}$ of icecold distilled water, respectively. The sample was prepared by centrifuging to remove the solution and adding $20 \mathrm{~mL}$ of distilled water, taking $0.5 \mathrm{~mL}$ of the mixture as sample. The standard solution $(10 \mu \mathrm{g} / \mathrm{mL}$ glucosamine) and blank control (distilled water) were prepared. $0.5 \mathrm{~mL}$ of water, $5 \%(\mathrm{w} / \mathrm{v}) \mathrm{NaNO}_{2}$, and $5 \%(\mathrm{w} / \mathrm{v}) \mathrm{KHSO}_{4}$ were added to $0.5 \mathrm{~mL}$ of the sample, and then gently mixed for $15 \mathrm{~min}$. The solution was then centrifuged at $10,000 \mathrm{rpm}$ for $5 \mathrm{~min}$ at $4^{\circ} \mathrm{C}$ to remove precipitation. A total of $0.5 \mathrm{~mL}$ of $12.5 \%(\mathrm{w} / \mathrm{v}) \mathrm{NH}_{4}$ sulfamate was added to the $0.5 \mathrm{~mL}$ sample and vigorously mixed for $5 \mathrm{~min}$. Then, $0.5 \mathrm{~mL}$ of an $0.5 \%(\mathrm{w} / \mathrm{v})$ newly prepared 3-methylbenzthiazolinone-2hydrazone solution was added. The sample was mixed and boiled for $3 \mathrm{~min}$. After cooling to room temperature, $0.5 \mathrm{~mL}$ of $0.83 \%$ $(\mathrm{w} / \mathrm{v}) \mathrm{FeCl}_{3} \cdot 6 \mathrm{H}_{2} \mathrm{O}$ was added. After being maintained at room temperature for $30 \mathrm{~min}$, the absorbance value was measured with a spectrophotometer at a wavelength of $650 \mathrm{~nm}$. According to formula (1), the glucosamine contention decomposed by chitin can be calculated.

$$
X=\frac{A-A_{0}}{A_{1}-A_{0}} \times 10
$$

where $X$ is the concentration of glucosamine $(\mu \mathrm{g} / \mathrm{mL}), A_{1}$ is the standard absorbance value, $A_{0}$ is the distilled water absorbance value, $A$ is the sample absorbance value, and 10 is the known glucosamine concentration $(\mu \mathrm{g} / \mathrm{mL})$.

\section{Statistical Analysis}

All the experiments were triplicated. The results were indicated as the mean \pm standard deviation by the SPSS 16.0 software (SPSS, Inc., Chicago, IL, United States). The data were analyzed by a oneway analysis of variance (ANOVA), and the differences between the means were determined by Tukey's multiple-range tests. The results were regarded as statistically significant at $P<0.05$.

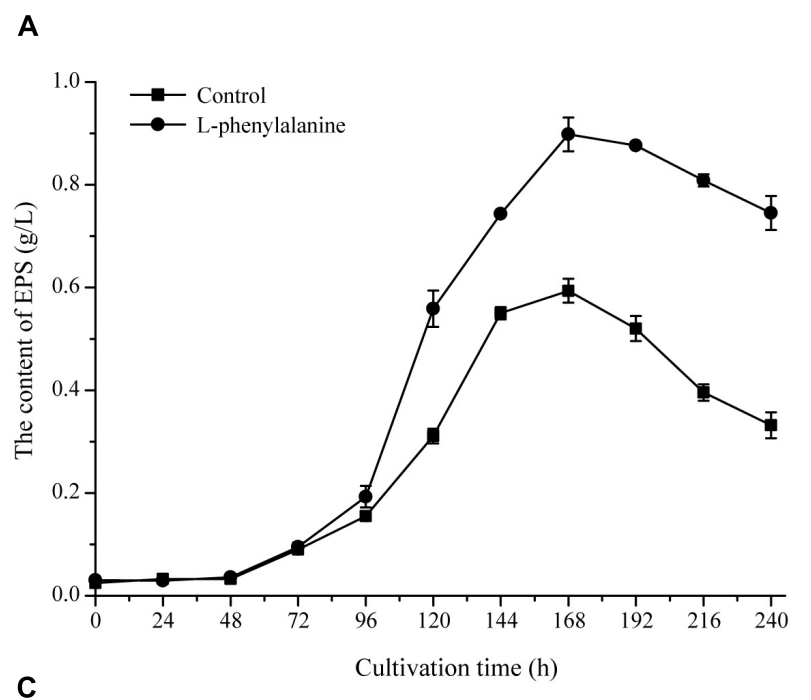

B
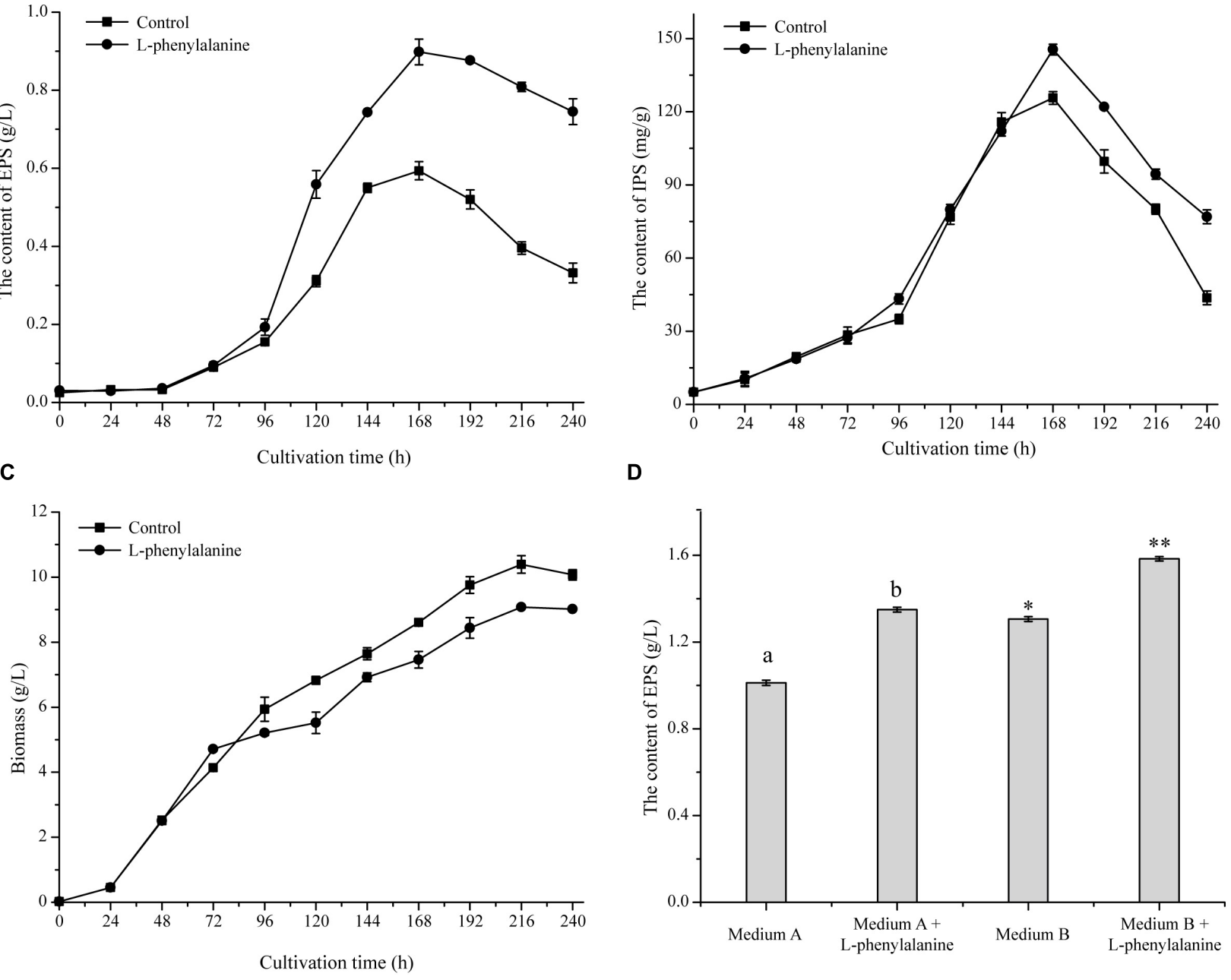

FIGURE 2 | Effect of L-phenylalanine on the yield of EPS (A), IPS (B), and cell growth (by biomass) (C). (D) The effect of L-phenylalanine on the yield of EPS in different culture media [the different superscript letters $(a, b)$ and symbols $\left({ }^{*},{ }^{*}\right)$ in each column indicate significant differences at the $P<0.05$ level]. 


\section{RESULTS AND DISCUSSION}

\section{Effect of L-Phenylalanine on the EPS Production of G. lucidum}

In the preliminary work of our laboratory, it was found that adding L-phenylalanine to a fermentation medium could improve the G. lucidum EPS yield based on the model iZBM 1060 (Ma et al., 2018). In order to test the effect of L-phenylalanine, different concentrations of L-phenylalanine were added to the medium of G. lucidum. As shown in Figure 1A, L-phenylalanine at $0.4 \mathrm{~g} / \mathrm{L}$ provided the maximal EPS production of $0.79 \mathrm{~g} / \mathrm{L}$, and EPS production increased by $45.49 \%$. In order to better understand the effects of

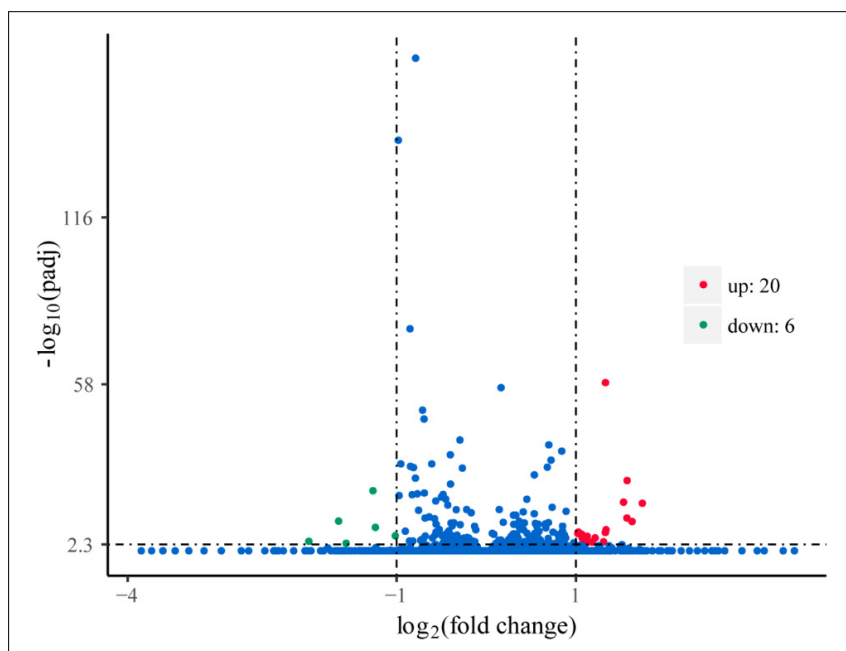

FIGURE 3 | Volcano plots of gene expression. The points of the green areas represent down-regulated genes, the points of the red areas represent up-regulated genes, and other points represent genes without significant change.<smiles></smiles>

L-phenylalanine<smiles>O=C(O)/C=C/c1ccccc1</smiles>

trans-Cinnamic acid<smiles>O=C(O)c1ccc(O)cc1</smiles>

4-Hydroxybenzoate

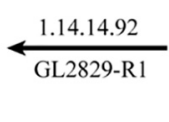

FIGURE 4 | The metabolic pathway of L-phenylalanine in G. Iucidum.

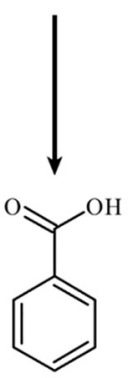

Benzoate
L-phenylalanine on the production of polysaccharides, $0.4 \mathrm{~g} / \mathrm{L}$ L-phenylalanine was added at different time periods. The EPS yield improved from 0.56 to $0.91 \mathrm{~g} / \mathrm{L}$ by adding $\mathrm{L}$-phenylalanine at $24 \mathrm{~h}$, leading to a $62.50 \%$ significant increase (Figure 1B). Thus, it can be seen that L-phenylalanine is very important to improve EPS synthesis efficiency. Accordingly, $0.4 \mathrm{~g} / \mathrm{L} \mathrm{L}$-phenylalanine added at $24 \mathrm{~h}$ was selected for subsequent studies.

The maximum specific EPS production rate [QEPS, calculated by the formula $(1 / X) \times\left(\mathrm{d} P_{\mathrm{EPS}} / \mathrm{d} t\right)$, where $X$ means cell biomass, and $P_{\text {EPS }}$ means EPS production] of G. lucidum was achieved by adding L-phenylalanine. As shown in Figure 2A, the QEPS reached $2.96 \mathrm{mg} / \mathrm{g} \mathrm{DW} / \mathrm{h}$, which was a 1.71 -fold increase compared to the control. The addition of L-phenylalanine also promoted the content of IPS, which increased to $145.51 \mathrm{mg} / \mathrm{g}$ DW, with a $15.79 \%$ increment (Figure 2B). The experimental results show that L-phenylalanine contributed to the improvement of QEPS and IPS concentration, thereby indicating that L-phenylalanine facilitated polysaccharide synthesis in the submerged G. lucidum culture. However, L-phenylalanine had a certain negative effect on the growth of G. lucidum and caused a $12.61 \%$ decrease in maximal biomass (Figure 2C).

Furthermore, the effects of L-phenylalanine on G. lucidum EPS production were tested in other reported culture media (Figure 2D). Results showed that the addition of L-phenylalanine could increase the maximum EPS yield by 1.33 -fold (medium A) and 1.21-fold (medium B). Due to the wide production and lower price of L-phenylalanine, it is economically feasible to use L-phenylalanine as an efficient intensification strategy to promote the EPS production of G. lucidum.

Indeed, L-phenylalanine could also promote the synthesis of the intended products in other culture systems. A high concentration of L-phenylalanine led to the highest phenylalanine ammonia-lyase activities and improved colchicine production (Sivakumar et al., 2004). L-phenylalanine had a stimulative effect on the production of phenylethanoid glycosides in Cistanche deserticola, and maximal phenylethanoid glycoside production at $1.5 \mathrm{mmol} / \mathrm{L}$ of L-phenylalanine was 1.13-fold higher than the control (Hu et al., 2014). A certain concentration of L-phenylalanine enhanced the flavonoid

TABLE 2 | The expression of genes related to polysaccharide biosynthesis.

\begin{tabular}{lllcc}
\hline EC no. & Gene ID & Enzyme name & \multicolumn{2}{c}{ Read count } \\
\cline { 3 - 5 } & & & L-phenylalanine & Control \\
\hline 5.4.2.2 & GL24280-R1 & $\begin{array}{l}\alpha \text {-phospho- } \\
\text { glucomutase } \\
\text { (PGM) }\end{array}$ & 73.19 & 64.93 \\
2.7.7.9 & GL25739-R1 & $\begin{array}{l}\text { UDP-glucose } \\
\text { pyrophosphorylase } \\
\text { (UGP) }\end{array}$ & 285.53 & 221.55 \\
5.3.1.9 & GL22245-R1 & $\begin{array}{l}\text { Phosphoglucose } \\
\text { isomerase (PGI) }\end{array}$ & 53.11 & 39.24 \\
5.3.1.8 & GL22193-R1 & $\begin{array}{l}\text { Phosphomannose } \\
\text { isomerase (PMI) }\end{array}$ & 31.01 & 22.60 \\
\end{tabular}



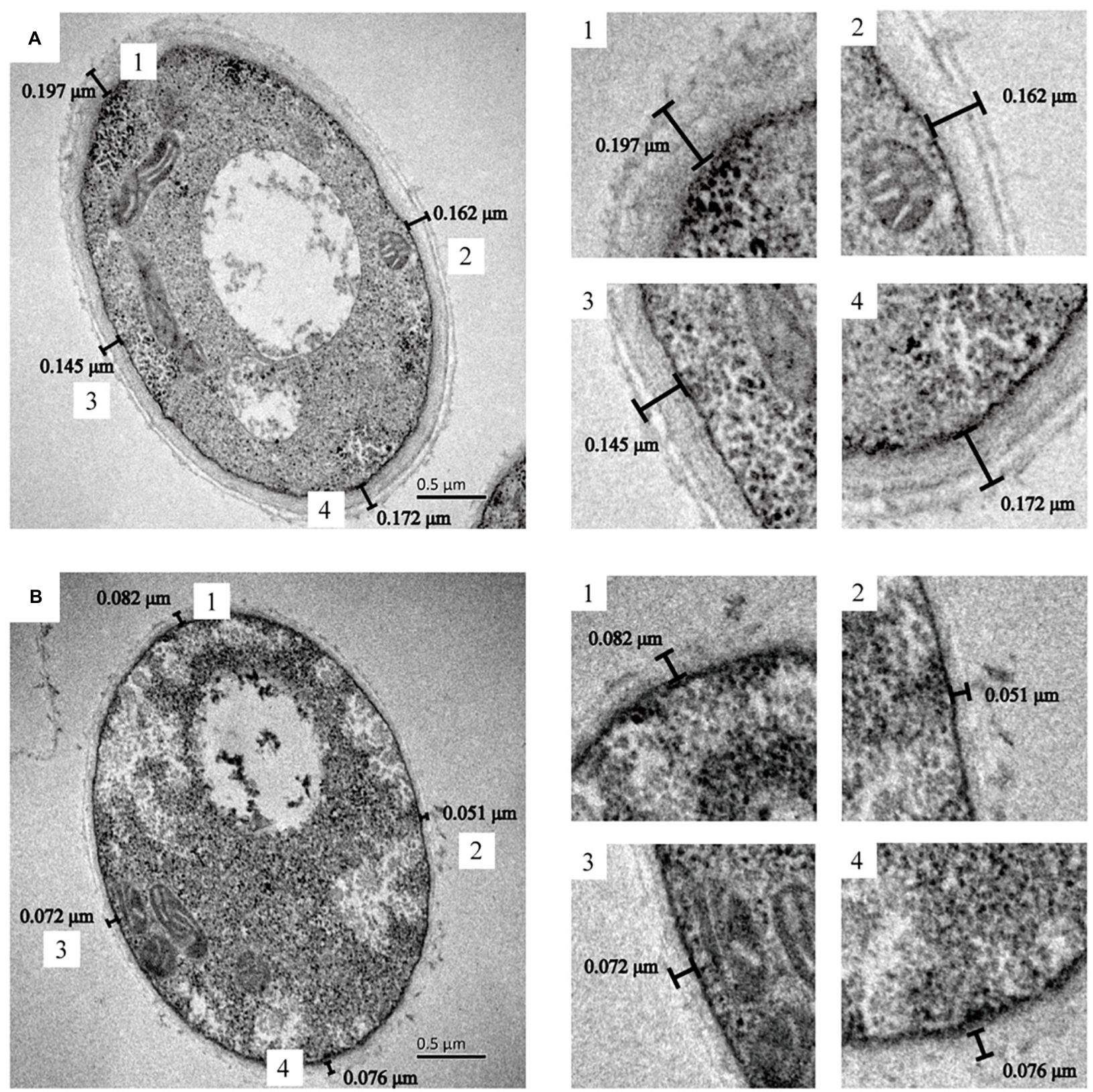

FIGURE 5 | G. lucidum cultured in several conditions. TEM pictures obtained after chemical fixation. (A) G. lucidum was cultivated at $30^{\circ} \mathrm{C}$ on a rotary shaker at $150 \mathrm{rpm}$. (B) G. lucidum was cultivated in a medium containing $0.4 \mathrm{~g} / \mathrm{L} \mathrm{L}$-phenylalanine, added at $24 \mathrm{~h}$.

production of Inonotus baumii (Mathur and Goswami, 2014; Li et al., 2018).

\section{Comparative Analysis of the G. Iucidum 5.26 Transcriptomes}

To explore the genes in response to L-phenylalanine, we compared the gene expression after L-phenylalanine treatment at a global level (Supplementary Table S1). The differentially expressed genes in G. lucidum under different culture conditions are displayed in Figure 3, a total of 20 up-regulated and 6 down-regulated genes. The 26 genes were annotated through the KAAS (Moriya et al., 2007) and UniProt (2010) databases. In the annotation results, two key enzymes related to L-phenylalanine metabolism were found to be up-regulated, and the cell wall synthesis related gene was found to be down-regulated.

Based on RT-qPCR analysis, the expression levels of two key enzymes related to L-phenylalanine metabolism, L-phenylalanine deaminase (pal, EC: 4.3.1.24, GL21534-R1), and benzoate 4hydroxylase (bpha, EC: 1.14.14.92, GL28294-R1) were upregulated by 264.27 and $125.81 \%$, respectively. L-phenylalanine deaminase catalyzes the deamination of L-phenylalanine and 

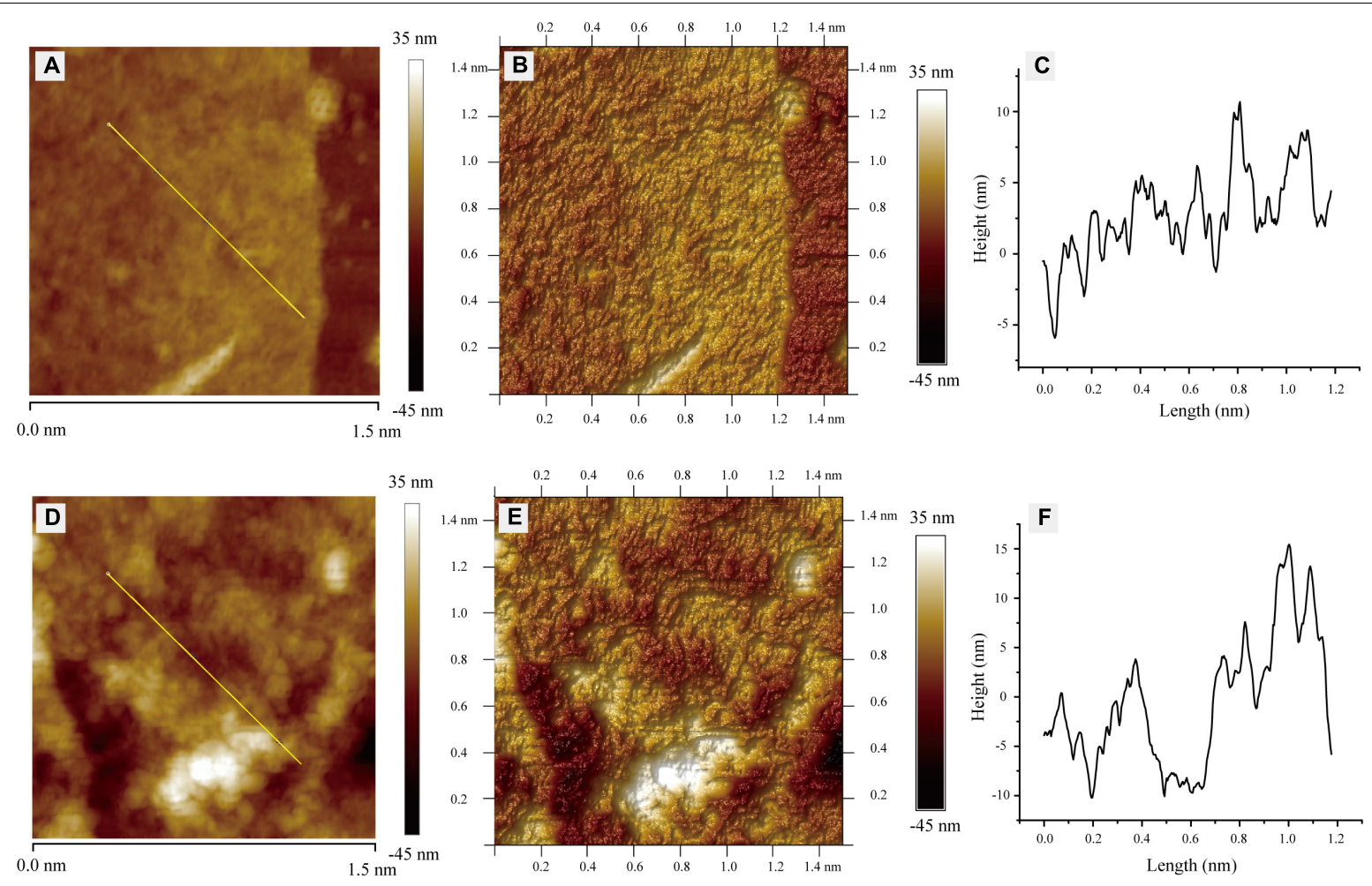

FIGURE 6 | Atomic force microscopy images of G. lucidum. (A) Two-dimensional image of G. lucidum. Straight line is for the line profile analysis. (B) Three-dimensional rendering of panel (A). (C) A height profile of over $1.2 \mu \mathrm{m}$ for straight line in panel (A). (D) Two-dimensional image of the L-phenylalanine-treated group. A straight line is for line profile analysis. (E) Three-dimensional rendering of panel (D). (F) The height profile over $1.2 \mu \mathrm{m}$ for a straight line in panel (D)

then produces trans-cinnamic acid. Benzoate 4-hydroxylase catalyzes the benzoate to form 4-hydroxybenzoate.

The possible metabolic pathway of L-phenylalanine in G. lucidum can be determined according to the results of the transcriptome analysis and genome annotation. L-phenylalanine deaminase catalyzed the deamination of L-phenylalanine to generate trans-cinnamic acid and benzoate accordingly, and then benzoate was catalyzed by benzoate 4-hydroxylase to form 4hydroxybenzoate (Figure 4).

Related studies have reported that L-phenylalanine has a hormonal effect. Short exposure to L-phenylalanine had no effect on Microcystis aeruginosa membrane integrity. However, after 24 and $48 \mathrm{~h}$ exposure, cells exposed to L-phenylalanine at concentrations between 1.25 and $20 \mu \mathrm{g} / \mathrm{mL}$ showed that L-phenylalanine efficiently inhibited the growth of $M$. aeruginosa by disrupting the cell membrane integrity and inhibiting esterase activity (Wei, 2011). In addition, the metabolites of L-phenylalanine, trans-cinnamic acid, and benzoate also had toxic effects in plants, thereby inhibiting the growth of plants. Zhang et al. (2009) reported that benzoate and cinnamic acids could cause the rapid and remarkable downregulation of genes related to the cell cycle, which resulted in the inhibition of cucumber root growth. Moreover, Salvador et al. (2013) found that externally added trans-cinnamic acid could be catalyzed into the phenylpropanoid pathway by trans-cinnamic acid 4-hydroxylase, thereby increasing the accumulation of p-hydroxyphenyl lignin. Meanwhile, as indole-3-acetate oxidase activity increased, related metabolic reactions proceeded to form hardened cell walls, which in turn led to reduced soybean root growth.

The benzoate 4-hydroxylase family was specific to fungi, and detoxification was the major function (Podobnik et al., 2008). Korosec et al. (2014) also proved that tans-cinnamic acid and its derivatives had antifungal activity mainly by inhibiting the activity of benzoate 4-hydroxylase. In this study, the addition of L-phenylalanine resulted in a lower biomass for G. lucidum, which may be due to the toxic effects from the metabolic intermediates of L-phenylalanine. The significant increase in the expression of the benzoate 4-hydroxylase gene in the L-phenylalanine metabolism of G. lucidum indirectly demonstrated the metabolism of L-phenylalanine to a benzoate.

RT-qPCR analysis showed that the expression level of the related cell wall mannoprotein gene (pir, GL18553-R1) was down-regulated by $35.83 \%$. As core components of the fungal cell wall, chitin and glucan need further modification by mannoproteins, so mannoproteins play a vital role in cell wall assembly (Orlean and Menon, 2007; Du et al., 2019). Moreover, the outer layer of the fungal cell wall is mainly formed by mannoprotein and $\beta$-glucan (Kollar et al., 1997). Hu et al. (2015) demonstrated that reduced transcription levels of genes encoding 
mannprotein had a negative impact on cell wall integrity. Thus, the decreasing expression of cell wall mannoprotein gene may lead to the growth inhibition of G. lucidum to a certain extent.

In addition, the results of transcriptome showed that the expressions of four genes involved in polysaccharide synthesis were increased compared with the control (Table 2). Researches demonstrated that increasing gene expression of UDP-glucose pyrophosphorylase (UGP), $\alpha$-phosphoglucomutase (PGM), phosphoglucose isomerase (PGI), and phosphomannose isomerase (PMI) facilitated polysaccharide production (Yang et al., 2013; Li et al., 2015; Xu et al., 2015; Han et al., 2017). Therefore, L-phenylalanine treatment increased the expression level of four genes related to polysaccharide synthesis, which should be one of the reasons for the increase of polysaccharide production.

\section{The Effect of L-Phenylalanine on the Biosynthesis of the G. Iucidum Cell Wall}

The cell wall thickness of G. lucidum was observed by TEM (Figure 5). There was a significant difference in mycelial cell wall thickness. The control cell wall $(0.169 \pm 0.02 \mu \mathrm{m})$ was approximately 2.5 -fold the thickness of the cells treated with L-phenylamine $(0.070 \pm 0.01 \mu \mathrm{m})$. This result proves that L-phenylalanine has a notable inhibitory effect on the cell wall synthesis of G. lucidum. The cell walls of fungi are important to maintain the cell's intrinsic morphology and the integrity of cells. A network of polysaccharides maintains normal cell metabolism, ion exchange, and osmotic pressure, and also enables the fungal cell to contact the external environment (Bowman and Free, 2006; Tavernier et al., 2018; OuYang et al., 2019). Therefore, a significant decrease in the cell wall's thickness may be beneficial to the secretion of polysaccharides.

In order to further study the effect of L-phenylalanine on the cell wall, the surface morphology of the G. lucidum cell wall was observed by AFM (Figure 6). The cell wall surfaces of the control showed an obviously tight network structure (Figure 6A). However, L-phenylalanine treatment had a certain destructive effect on the network structure integrity of the cell wall surface (Figure 6D). In the three-dimensional rendering, the difference in surface fluctuation was more obvious than that of the twodimensional images (Figures 6B,E). L-phenylalanine treatment resulted in more pores in the network structure of the cell wall surface, which may be related to the fact that the outer layer of the fungal cell wall was mainly composed of cell wall mannoprotein and $\beta$-glucan. In section "Comparative Analysis of the G. lucidum 5.26 Transcriptomes," it was also seen that the addition of L-phenylalanine down-regulated the expression of the cell wall mannoprotein gene by $35.83 \%$. The line profile showed surface fluctuations, revealing the significant height differences between the network structure under culture conditions without and with L-phenylalanine (Figures 6C,F). The maximum height of the cell wall surface without L-phenylalanine was $10.69 \mathrm{~nm}$, and the maximum depth was $5.92 \mathrm{~nm}$. The maximum height of the cell wall surface with L-phenylalanine was $15.44 \mathrm{~nm}$, and the maximum depth was $10.21 \mathrm{~nm}$. This result illustrates the negative effect of L-phenylalanine on the cell wall integrity of G. lucidum.

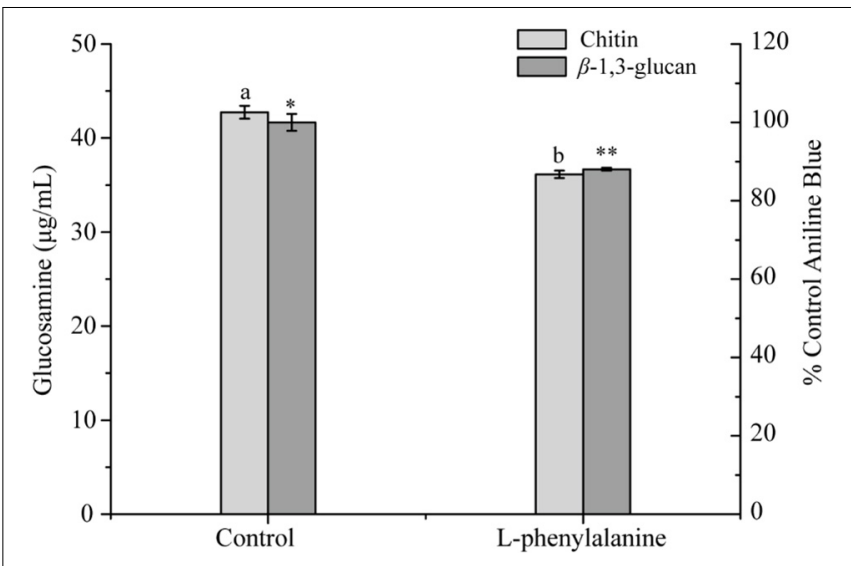

FIGURE 7 | Chitin and $\beta$-1,3-glucan concentrations in G. lucidum [the different superscript letters $(a, b)$ and symbols $\left({ }^{*},{ }^{* *}\right)$ in each column indicate significant differences at the $P<0.05$ level].

The contents of chitin and $\beta$-1,3-glucan in the cell wall of $G$. lucidum were determined. The results showed that after phenylalanine treatment, the contents of chitin and $\beta$ 1,3-glucan were significantly reduced by 15.44 and $11.97 \%$, respectively, compared with the control (Figure 7). Chitin has great tensile strength and contributes to the integrity of cell walls (Bowman and Free, 2006). In addition, $\beta$-glucan and cell wall mannoprotein, as the main components of the outer layer of the cell wall of fungi, play an important role in the outer structure of the cell wall. It has been suggested that a decrease in chitin and $\beta$ 1,3 -glucan content would result in great damage to the integrity of the cell wall (Kollar et al., 1997). The results were consistent with those observed by TEM and AFM.

Mannoproteins plays a crucial role in cell wall assembly and can further modify chitin and glucan. Moreover, mannoproteins are also directly related to cell wall porosity. A decrease in mannoproteins will increase the porosity of the cell wall (Zlotnik et al., 1984; De Nobel et al., 1989). Therefore, a decrease in the G. lucidum cell wall thickness and an increase of the cell wall pores may be mainly caused by the down-regulated expression level of the cell wall mannoprotein gene. In addition, the cell wall probably acts as a molecular sieve, and its porosity directly determines macromolecules' exportation abilities (De Nobel and Barnett, 1991). It has been certified that yeast macromolecule secretion is linked to high cell wall porosity (Boivin et al., 1998). In Figure 2A, after L-phenylalanine treatment, the mycelium QEPS increased 1.71-fold compared with the control. Therefore, a decrease in cell wall thickness and an increase in cell wall pores probably facilitated the secretion rate of EPS, thereby leading to increased EPS production.

\section{CONCLUSION}

The EPS production of G. lucidum increasing by $62.50 \%$ by adding $0.4 \mathrm{~g} / \mathrm{L}$ L-phenylalanine after a $24 \mathrm{~h}$ culture. The possible metabolic pathway of L-phenylalanine in G. lucidum 
was deduced. Additionally, L-phenylalanine and its metabolic intermediates promoted the production of IPS and had a significant inhibitory effect on the cell wall synthesis of G. lucidum. In conclusion, considering the wide production range and low price of L-phenylalanine, it is economically feasible to increase the EPS production of G. lucidum by L-phenylalanine.

\section{DATA AVAILABILITY STATEMENT}

The datasets analyzed in this manuscript are not publicly available. Requests to access the datasets should be directed to bioding@163.com.

\section{AUTHOR CONTRIBUTIONS}

$\mathrm{ZM}$ and $\mathrm{ZD}$ designed the experiments. $\mathrm{ZM}, \mathrm{MX}$, and QW performed the experiments. ZM, FW, HZ, ZG, YL,

\section{REFERENCES}

Armando, M. R., Pizzolitto, R. P., Dogi, C. A., Cristofolini, A., Merkis, C., Poloni, V., et al. (2012). Adsorption of ochratoxin a and zearalenone by potential probiotic Saccharomyces cerevisiae strains and its relation with cell wall thickness. J. Appl. Microbiol. 113, 256-264. doi: 10.1111/j.1365-2672.2012. 05331.x

Boivin, S., Feuillat, M., Alexandre, H., and Charpentier, C. (1998). Effect of must turbidity on cell wall porosity and macromolecule excretion of Saccharomyces cerevisiae cultivated on grape juice. Am. J. Enol. Viticult. 49, 325-332. doi: 10.1002/abio.370180412

Bongaerts, J., Kramer, M., Muller, U., Raeven, L., and Wubbolts, M. (2001). Metabolic engineering for microbial production of aromatic amino acids and derived compounds. Metab. Eng. 3, 289-300. doi: 10.1006/mben.2001.0196

Bowman, S. M., and Free, S. J. (2006). The structure and synthesis of the fungal cell wall. Bioessays 28, 799-808. doi: 10.1002/bies.20441

Chen, L., Zhang, B. B., and Cheung, P. C. (2012). Comparative proteomic analysis of mushroom cell wall proteins among the different developmental stages of Pleurotus tuber-regium. J. Agr. Food Chem. 60, 6173-6182. doi: 10.1021/ jf301198b

De Nobel, J. G., and Barnett, J. A. (1991). Passage of molecules through yeast cell walls: a brief essay-review. Yeast 7, 313-323. doi: 10.1002/yea.320070402

De Nobel, J. G., Dijkers, C., Hooijberg, E., and Klis, F. M. (1989). Increased cell wall porosity in Saccharomyces cerevisiae after treatment with dithiothreitol or EDTA. J.Gen. Microbiol. 135, 2077-2084. doi: 10.1099/00221287-135-7-2077

Du, T., Ouyang, H., Voglmeir, J., Wilson, I. B. H., and Jin, C. (2019). Aspergillus fumigatus Mnn9 is responsible for mannan synthesis and required for covalent linkage of mannoprotein to the cell wall. Fungal Genet. Biol. 128, 20-28. doi: 10.1016/j.fgb.2019.03.006

Dubois, M., Gilles, K., Hamilton, J. K., Rebers, P. A., and Smith, F. (1951). A colorimetric method for the determination of sugars. Nature 168:167. doi: 10.1038/168167a0

Ferreira, I. C., Heleno, S. A., Reis, F. S., Stojkovic, D., Queiroz, M. J., Vasconcelos, M. H., et al. (2015). Chemical features of ganoderma polysaccharides with antioxidant, antitumor and antimicrobial activities. Phytochemistry 114, 38-55. doi: 10.1016/j.phytochem.2014.10.011

Fortwendel, J. R., Juvvadi, P. R., Pinchai, N., Perfect, B. Z., Alspaugh, J. A., Perfect, J. R., et al. (2009). Differential effects of inhibiting chitin and 1,3-beta-D-glucan synthesis in ras and calcineurin mutants of Aspergillus fumigatus. Antimicrob. Agents Chemother. 53, 476-482. doi: 10.1128/AAC.01154-08

Gu, L., Zhong, X., Lian, D., Zheng, Y., Wang, H., and Liu, X. (2017). Triterpenoid biosynthesis and the transcriptional response elicited by nitric oxide in submerged fermenting ganoderma lucidum. Process. Biochem. 60, 19-26. doi: 10.1016/j.procbio.2017.05.029
GS, and ZD conceived the project, analyzed the data, and wrote the manuscript.

\section{FUNDING}

This research was funded by the National Natural Science Foundation of China (31271918), the China Postdoctoral Science Foundation (2015M571691), Qing Lan Project, and national first-class discipline program of Light Industry Technology and Engineering (LITE2018-22).

\section{SUPPLEMENTARY MATERIAL}

The Supplementary Material for this article can be found online at: https://www.frontiersin.org/articles/10.3389/fmicb. 2019.02306/full\#supplementary-material

Guan, N., Du, B., Li, J., Shin, H. D., Chen, R. R., Du, G., et al. (2018). Comparative genomics and transcriptomics analysis-guided metabolic engineering of propionibacterium acidipropionici for improved propionic acid production. Biotechnol. Bioeng. 115, 483-494. doi: 10.1002/bit.26478

Han, P. P., Yao, S. Y., Guo, R. J., Yan, R. R., Wu, Y. K., Shen, S. G., et al. (2017). Influence of culture conditions on extracellular polysaccharide production and the activities of enzymes involved in the polysaccharide synthesis of Nostoc flagelliforme. RSC Adv. 7, 45075-45084. doi: 10.1039/c7ra $07982 \mathrm{f}$

Hu, G. S., Jia, J. M., and Doh Hoon, K. (2014). Effects of feeding tyrosine and phenylalanine on the accumulation of phenylethanoid glycosides to Cistanche deserticola cell suspension culture. Chin. J. Nat. Med. 12, 367-372. doi: 10.3724/ sp.j.1009.2014.00367

Hu, P. J., Wang, Y., Zhou, J., Pan, Y. Y., and Liu, G. (2015). AcstuA, which encodes an APSES transcription regulator, is involved in conidiation, cephalosporin biosynthesis and cell wall integrity of Acremonium chrysogenum. Fungal Genet. Biol. 83, 26-40. doi: 10.1016/j.fgb2015.08.003

Hu, Y., Li, M., Wang, S., Yue, S., Shi, L., Ren, A., et al. (2018). Ganoderma lucidum phosphoglucomutase is required for hyphal growth, polysaccharide production, and cell wall integrity. Appl. Microbiol. Biot. 102, 1911-1922. doi: 10.1007/s00253-017-8730-6

Kim, M., Kim, K. W., and Jung, H. S. (2007). Morphological discretion of basidiospores of the puffball mushroom calostoma by electron and atomic force microscopy. J. Microbiol. Biotechn. 17, 1721-1726. doi: 10.1016/j.mimet.2007. 08.002

Kollar, R., Reinhold, B. B., Petrakova, E., Yeh, H. J. C., Ashwell, G., Drgonova, J., et al. (1997). Architecture of the yeast cell wall: beta (1-6)-glucan interconnects mannoprotein, beta (1-3)-glucan, and chitin. J. Biol. Chem. 272, 17762-17775. doi: $10.1074 /$ jbc.272.28.17762

Korosec, B., Sova, M., Turk, S., Krasevec, N., Novak, M., Lah, L., et al. (2014). Antifungal activity of cinnamic acid derivatives involves inhibition of benzoate 4-hydroxylase (CYP53). J. Appl. Microbiol. 116, 955-966. doi: 10.1111/jam. 12417

Li, H., Jiao, X., Zhou, W., Sun, Y., Liu, W., Lin, W., et al. (2018). Enhanced production of total flavones from Inonotus baumii by multiple strategies. Prep. Biochem. Biote. 48, 103-112. doi: 10.1080/10826068.2017.1365248

Li, J. Q., Zhang, J. H., Chen, H. M., Chen, X. D., Lan, J., and Liu, C. (2013). Complete mitochondrial genome of the medicinal mushroom ganoderma lucidum. PLoS One 8:12. doi: 10.1371/journal.pone.0072038

Li, M. J., Chen, T. X., Gao, T., Miao, Z. G., Jiang, A. L., Shi, L., et al. (2015). UDP-glucose pyrophosphorylase influences polysaccharide synthesis, cell wall components, and hyphal branching in ganoderma lucidum via regulation of the balance between glucose-1-phosphate and UDP-glucose. Fungal Genet. Biol. 82, 251-263. doi: 10.1016/j.fgb.2015.07.012 
Liu, W., Xu, J., Jing, P., Yao, W., Gao, X., and Yu, L. (2010). Preparation of a hydroxypropyl ganoderma lucidum polysaccharide and its physicochemical properties. Food Chem. 122, 965-971. doi: 10.1016/j.foodchem.2009.11.087

Liu, Y., Xin, Z. Z., Song, J., Zhu, X. Y., Liu, Q. N., Zhang, D. Z., et al. (2018). Transcriptome analysis reveals potential antioxidant defense mechanisms in Antheraea pernyi in response to zinc stress. J. Agr. Food Chem. 66, 8132-8141. doi: 10.1021/acs.jafc.8b01645

Livak, K. J., and Schmittgen, T. D. (2001). Analysis of relative gene expression data using real-time quantitative PCR and the 2(T)(-Delta Delta C) method. Methods 25, 402-408. doi: 10.1006/meth.2001.1262

Ma, Z., Ye, C., Deng, W., Xu, M., Wang, Q., Liu, G., et al. (2018). Reconstruction and analysis of a genome-scale metabolic model of ganoderma lucidum for improved extracellular polysaccharide production. Front. Microbiol. 9:3076. doi: $10.3389 /$ fmicb. 2018.03076

Mathur, S., and Goswami, A. (2014). Effect of precursor $\beta$-phenylalanine on production of flavonoids of maytenus emarginata in vitro. Int. J. Sci. Res. 3, 333-335.

Moriya, Y., Itoh, M., Okuda, S., Yoshizawa, A. C., and Kanehisa, M. (2007). KAAS: an automatic genome annotation and pathway reconstruction server. Nucleic Acids Res. 35, W182-W185. doi: 10.1093/nar/gkm321

Orlean, P., and Menon, A. K. (2007). Thematic review series: lipid posttranslational modifications. GPI anchoring of protein in yeast and mammalian cells, or: how we learned to stop worrying and love glycophospholipids. J. Lipid Res. 48, 993-1011. doi: 10.1194/jlr.R700002-JLR200

OuYang, Q. L., Duan, X. F., Li, L., and Tao, N. G. (2019). Cinnamaldehyde exerts its antifungal activity by disrupting the cell wall integrity of geotrichum citri-aurantii. Front. Microbiol. 10:9. doi: 10.3389/fmicb.2019.00055

Peng, L., Qiao, S., Xu, Z., Guan, F., Ding, Z., Gu, Z., et al. (2015). Effects of culture conditions on monosaccharide composition of ganoderma lucidum exopolysaccharide and on activities of related enzymes. Carbohyd. Polym. 133, 104-109. doi: 10.1016/j.carbpol.2015.07.014

Podobnik, B., Stojan, J., Lah, L., Krasevec, N., Seliskar, M., Rizner, T. L., et al. (2008). CYP53A15 of Cochliobolus lunatus, a target for natural antifungal compounds. J. Med. Chem. 51, 3480-3486. doi: 10.1021/jm800030e

Robinson, M. D., McCarthy, D. J., and Smyth, G. K. (2010). edgeR: a bioconductor package for differential expression analysis of digital gene expression data. Bioinformatics 26, 139-140. doi: 10.1093/bioinformatics/btp616

Salvador, V. H., Lima, R. B., dos Santos, W. D., Soares, A. R., Bohm, P. A. F., Marchiosi, R., et al. (2013). Cinnamic acid increases lignin production and inhibits soybean root growth. PLoS One 8:10. doi: 10.1371/journal.pone. 0069105

Sivakumar, G., Krishnamurthy, K. V., Hao, J., and Paek, K. Y. (2004). Colchicine production in Gloriosa superba calluses by feeding precursors. Chem. Nat. Comp. 40, 499-502. doi: 10.1007/s10600-005-0020-3

Stajic, M., Glamoclija, J., Maksimovic, V., Vukojevic, J., Simonic, J., and Zervakis, G. (2011). A comparative assessment of the potential of polysaccharide production and intracellular sugar composition within lingzhi or reishi medicinal mushroom, ganoderma lucidum (W.Curt.:Fr.)P. Karst (Aphyllophoromycetideae). Int. J. Med. Mushrooms 13, 153-158. doi: 10.1615/IntJMedMushr.v13.i2.70

Storey, J. D. (2003). The positive false discovery rate: a bayesian interpretation and the q-value. Ann. Stat. 31, 2013-2035. doi: 10.1214/aos/107429 0335

Tang, Y. J., and Zhong, J. J. (2002). Fed-batch fermentation of ganoderma lucidum for hyperproduction of polysaccharide and ganoderic acid. Enzyme Microb. Tech. 31, 20-28. doi: 10.1016/s0141-0229(02)00066-2

Tavernier, S., Sass, A., De Bruyne, M., Baeke, F., De Rycke, R., Crabbe, A., et al. (2018). Decreased susceptibility of Streptococcus anginosus to vancomycin in a multispecies biofilm is due to increased thickness of the cell wall. J. Antimicrob. Chemoth. 73, 2323-2330. doi: 10.1093/jac/dky216
UniProt, C. (2010). The universal protein resource (uniprot) in 2010. Nucleic Acids Res. 38, D142-D148. doi: 10.1093/nar/gkp846

Wei, H. (2011). Effects and mechanisms of L-phenylalanine on growth of Microcystis aeruginosa. J. Southeast Univ. 27, 445-448. doi: 10.3969/j.issn.10037985.2011.04.019

Wei, Z. H., Chen, N., Li, Y. J., Fan, Q. L., Yu, T. F., Wang, K. X., et al. (2018). Glucose fed-batch integrated dissolved oxygen control strategy enhanced polysaccharide, total triterpenoids and inotodiol production in fermentation of a newly isolated Inonotus obliquus strain. Process. Biochem. 66, 1-6. doi: 10.1016/j.procbio.2018.01.006

Wei, Z. H., Liu, L., Guo, X. F., Li, Y. J., Hou, B. C., Fan, Q. L., et al. (2016). Sucrose fed-batch strategy enhanced biomass, polysaccharide, and ganoderic acids production in fermentation of ganoderma lucidum 5.26. Bioproc. Biosyst. Eng. 39, 37-44. doi: 10.1007/s00449-015-1480-x

Xiang, Q., Yu, Q., Wang, H., Zhao, M., Liu, S., Nie, S., et al. (2018). Immunomodulatory effect of ganoderma atrum polysaccharides on Th17/Treg balance. J. Funct. Foods 45, 215-222. doi: 10.1016/j.jff.2018.03.020

Xu, J. W., Ji, S. L., Li, H. J., Zhou, J. S., Duan, Y. Q., Dang, L. Z., et al. (2015). Increased polysaccharide production and biosynthetic gene expressions in a submerged culture of ganoderma lucidum by the overexpression of the homologous alpha-phosphoglucomutase gene. Bioproc. Biosyst. Eng. 38, 399-405. doi: 10.1007/s00449-014-1279-1

$\mathrm{Xu}$, J. W., Xu, Y. N., and Zhong, J. J. (2010). Production of individual ganoderic acids and expression of biosynthetic genes in liquid static and shaking cultures of ganoderma lucidum. Appl. Microbiol. Biot. 85, 941-948. doi: 10.1007/s00253009-2106-5

Yang, H., Min, W., Bi, P., Zhou, H., and Huang, F. (2013). Stimulatory effects of coix lacryma-jobi oil on the mycelial growth and metabolites biosynthesis by the submerged culture of ganoderma lucidum. Biochem. Eng. J. 76, 77-82. doi: 10.1016/j.bej.2013.04.012

Zhang, Y., Gu, M., Xia, X. J., Shi, K., Zhou, Y. H., and Yu, J. Q. (2009). Effects of phenylcarboxylic acids on mitosis, endoreduplication and expression of cell cycle-related genes in roots of cucumber (cucumis sativus L). J. Chem. Ecol. 35, 679-688. doi: 10.1007/s10886-009-9642-4

Zhen, D., Su, L., Miao, Y., Zhao, F., Ren, G., Mahfuz, S., et al. (2018). Purification, partial characterization and inducing tumor cell apoptosis activity of a polysaccharide from ganoderma applanatum. Int. J. Biol. Macromol. 115, 10-17. doi: 10.1016/j.ijbiomac.2018.03.062

Zhou, H., Liu, G., Huang, F., Wu, X., and Yang, H. (2014). Improved production, purification and bioactivity of a polysaccharide from submerged cultured ganoderma lucidum. Arch. Pharm. Res. 37, 1530-1537. doi: 10.1007/s12272014-0391-8

Zlotnik, H., Fernandez, M. P., Bowers, B., and Cabib, E. (1984). Saccharomyces cerevisiae mannoproteins form an external cell wall layer that determines wall porosity. J. Bacteriol. 159, 1018-1026. doi: 10.1111/j.1365-2672.1984.tb01383.x

Conflict of Interest: HZ was employed by Jiangsu Alphay Biological Technology Co., Ltd.

The remaining authors declare that the research was conducted in the absence of any commercial or financial relationships that could be construed as a potential conflict of interest.

Copyright (c) 2019 Ma, Xu, Wang, Wang, Zheng, Gu, Li, Shi and Ding. This is an open-access article distributed under the terms of the Creative Commons Attribution License (CC BY). The use, distribution or reproduction in other forums is permitted, provided the original author(s) and the copyright owner(s) are credited and that the original publication in this journal is cited, in accordance with accepted academic practice. No use, distribution or reproduction is permitted which does not comply with these terms. 